\title{
First-line antiretroviral therapy and dyslipidemia in people living with HIV-1 in Cameroon: a cross-sectional study
}

Eric Walter Pefura Yone ${ }^{1,2^{*}}$, Awa Foueudjeu Betyoumin ${ }^{3}$, André Pascal Kengne ${ }^{4}$, François Jérome Kaze Folefack ${ }^{2,5}$ and Jeanne Ngogang ${ }^{2,3}$

\begin{abstract}
Background: Data on lipid profile derangements induced by antiretroviral treatment in Africa are scarce. The aim of this study was to determine the prevalence and characteristics of lipid profile derangements associated with first-line highly active antiretroviral therapy (ART) among Cameroonians living with human immunodeficiency virus (HIV) infection.

Methods: This cross-sectional study was conducted between November 2009 and January 2010, and involved 138 HIV patients who had never received ART (ART-naive group) and 138 others treated for at least 12 months with first line triple ART regimens that included nevirapine or efavirenz (ART group). Lipid profile was determined after overnight fast and dyslipidemia diagnosed according to the US National Cholesterol Education Program III criteria. Data comparison used chi-square test, Student t-test and logistic regressions.

Results: The prevalence of total cholesterol $\geq 200 \mathrm{mg} / \mathrm{dl}$ was $37.6 \%$ and $24.6 \%$ respectively in ART group and ARTnaive groups ( $p=0.019$ ). The equivalents for LDL-cholesterol $\geq 130 \mathrm{mg} / \mathrm{dl}$ were $46.4 \%$ and $21 \%(p \leq 0.001)$. Proportions of patients with total cholesterol/HDL-cholesterol ratio $\geq 5$ was $35.5 \%$ in ART group and $18.6 \%$ in ART-naive group ( $p \leq$ 0.001). The distribution of HDL-cholesterol and triglycerides was similar between the two groups. In multivariable analysis adjusted for age, sex, body mass index, CD4 count and co-infection with tuberculosis, being on ART was significantly and positively associated with raised total cholesterol, LDL-cholesterol and TC/HDL cholesterol. The adjusted odd ratios (95\% confidence interval, $\mathrm{p}$-value) ART-treated vs. ART-naïve was $1.82(1.06-1.12, \mathrm{p}=0.02)$ for TC $\geq$ $200 \mathrm{mg} / \mathrm{dl} ; 2.99$ (1.74-5.15), $\mathrm{p}<0.0001)$ for LDL-cholesterol $\geq 130 \mathrm{mg} / \mathrm{dl}$ and $1.73(1.04-2.89, \mathrm{p}=0.03)$ for TC/HDLcholesterol $\geq 5$.

Conclusions: First-line antiretroviral therapy that includes nonnucleoside reverse transcriptase inhibitors is associated with pro-atherogenic adverse lipid profile in people with HIV-1 infection compared to untreated HIVinfected subjects in Yaounde. Lipid profile and other cardiovascular risk factors should be monitored in patients on such therapy so that any untoward effects of treatments can be optimally managed.
\end{abstract}

Keywords: antiretroviral therapy, dyslipidemia, HIV, Cameroon

\section{Introduction}

The advent of highly active antiretroviral therapy (HAART) has modified the natural history of human immunodeficiency virus (HIV) infection through reduction in risks of death associated with the condition and improvement of the quality of life of people living with the infection $[1,2]$. However, antiretroviral drugs also

\footnotetext{
* Correspondence: pefura2002@yahoo.fr

${ }^{1}$ Chest Unit of Yaounde Jamot Hospital, Cameroon

Full list of author information is available at the end of the article
}

have side effects of varying order of severity. Derangements of lipid metabolism associated with HAART have been largely characterised in the West and in several developing countries, particularly in patients on treatment regimens including protease inhibitors (PIs) and stavudine [3,4], but also for treatment regimens including nevirapine and efavirenz [5,6]. Antiretroviral therapy (ART) can induce raised levels of total cholesterol (TC), LDL-cholesterol (LDL-c) and triglycerides (TG), and variables effects on HDL-cholesterol (HDL-c) levels [4].
C Biomed Central

() 2011 Pefura Yone et al; licensee BioMed Central Ltd. This is an Open Access article distributed under the terms of the Creative Commons Attribution License (http://creativecommons.org/licenses/by/2.0), which permits unrestricted use, distribution, and reproduction in any medium, provided the original work is properly cited. 
These ART-induced lipid derangements are potentially atherogenic and can increase cardiovascular risk $[7,8]$. First-line HAART regimens as defined by the World Health Organisation (WHO) and that are largely used in resources-constrained countries do not include PIs $[9,10]$. Evidences in support of lipid profile derangements associated with HAART in sub-Saharan Africa are scarce $[11,12]$. The aim of the present study was to determine the prevalence and determinants of derangements in lipid profile associated with the use of first-line ART regimens in Cameroonians with HIV infection.

\section{Participants and Methods \\ Study setting and Participants}

This was a cross-sectional study. Participants were recruited between November 2009 and January 2010 at the registered treatment centre of the Yaounde Jamot's Hospital. Two groups of participants were selected. One group included individuals with HIV-1 infection and who had been receiving ART for at least 12 months, based on WHO first-line regimens (ART group). First-line ART regimens applied to these participants were those that included lamivudine (3TC), stavudine ( $\mathrm{d} 4 \mathrm{~T}$ ) or zidovudine (AZT), and nevirapine (NVP) or efavirenz (EFV). The choice of regimens was unrelated to potential factors that could induce a dyslipidemia, given that lipid profile assessment is not part of routine pre-ART treatment evaluation in this setting [9]. Patients who had had their treatment regimens changed during follow-up were excluded. The second group was made up of individuals newly diagnosed with HIV-1 infection and who were not yet receiving ART (ART-naïve group). Participants had to be at least 18 years of age and to have a treatment adherence rate $\geq 95 \%$ (for the treated group). Level of adherence was assessed by verbal administration of a standard series of questions adapted from Adult AIDS clinical trials group (AACTG) adherence instruments. The $95 \%$ rate of adherence is referable to 4-day recall data [13]. Participants were also required not to be on lipid modifying therapies at their enrolment. All participants gave their inform consent and the study was approved by the Cameroon National Ethic Committee (ref N ${ }^{\circ} 150 / \mathrm{CNE} / \mathrm{SE} / 09$ ).

\section{Methods}

For each participant, data were collected on the sociodemographic background, past medical history including the use of medications that could modify the lipid profile and active or history of tuberculosis. ART-naïve participants were screened for HIV-1 and HIV-2 infection with the use of a rapid test (DETERMINE HIV 1-2, Abbott, Tokyo, Japan). Those whose' screening test was positive had their status confirmed with a $3^{\text {rd }}$ generation immunochromatographic test (HEXAGON HIV, Human Laboratory, Wiesbaden, Germany). Lymphocytes count for all participants used flux cytometry methods implemented with BD FASCOUNT automate (BD Biosciences, Le pont de Claix, France). Lipid profile was assessed through enzymatic methods (Linear chemicals, Montgat, Spain) for all patients and included total cholesterol (TC), HDL-cholesterol (HDL-c), LDL-cholesterol (LDL-c) and triglycerides (TG). To this end, blood sample was collected after an overnight fast (12 hours) and centrifuged at 3000 cycles/ minute, and the serum obtained was then used for lipids determination. The TC/HDL-c ratio was also calculated. In accordance with the US National Cholesterol Education Program, Adult Treatment Panel III (NCEP-ATP III) guidelines, abnormal lipid profile was defined as TC $\geq 200$ $\mathrm{mg} / \mathrm{dl}, \mathrm{HDL}-\mathrm{c}<40 \mathrm{mg} / \mathrm{dl}, \mathrm{LDL}-\mathrm{c} \geq 130 \mathrm{mg} / \mathrm{dl}$, TG $\geq 150$ $\mathrm{mg} / \mathrm{dl}$ and TC/HDL-c ratio $\geq 5[14]$.

\section{Statistical analysis}

Sample size was determined assuming a 5\% prevalence of total cholesterol $>200 \mathrm{mg} / \mathrm{dl}$ in patients ART-naïve patient, a minimum detectable unadjusted odds ratio (OR) of 2, a Type I error of $5 \%$ and a power of $80 \%$ [11]. Based on the above, the required sample size was 268 participants (134 ART-naïve and 134 ART-treated patients). Data analysis used Statical package for social sciences (SPSS) version 17 for Windows (SPSS, Chicago, IL). Differences in means and proportions for participants' characteristics were assessed using Student t-test and $\chi^{2}$ tests and variants as applicable, and the influence of likely confounders adjusted for through logistic regressions models. Potential predictors consider for inclusion in models were those found to be correlated with lipid abnormalities during ART elsewhere [11,15]. A probability threshold of $P<0.05$ was set as the threshold of statistical significance.

\section{Results}

\section{Characteristics of the study population}

In all, 138 participants on ART and 138 ART-naïve participants were included. Sixty-eight (49.3\%) patients in the ART-naïve group had active tuberculosis and 55 (39.6\%) in the ART group had had tuberculosis prior to been started on ART. Meanwhile, no patient in the ART group had active tuberculosis at inclusion in the study. First-line ART regimens were as followed: $\mathrm{d} 4 \mathrm{~T} / 3 \mathrm{TC} / \mathrm{NVP}$ (61 participants), d4T/3TC/EFV (32 participants), AZT/3TC/NVP (31 participants) and AZT/3TC/EFV (14 participants). Therefore among ART patients, 93 (64.4\%) participants were on d4T, $45(32.6 \%)$ on AZT, $92(66.7 \%)$ on NVP and 46 (33.3\%) on EFV. All regimens included 3TC. ART patients had been on treatment for an average of 30 months (standard deviation: 13). The profile of participants is described in Table 1. There was no significant difference between the ART group and ART-naive group for age ( 40.6 vs. 38.7 years, $p=0.07)$, sex distribution (\% men: 
Table 1 Profile of 138 ART-naïve and 138 first-line ART treated individuals in Yaounde, Cameroon

\begin{tabular}{llll}
\hline Characteristics & $\begin{array}{l}\text { First-line ART-treated } \\
(\mathbf{n}=\mathbf{1 3 8})\end{array}$ & $\begin{array}{l}\text { ART-naïve } \\
(\mathbf{n}=\mathbf{1 3 8})\end{array}$ & $\mathbf{p}$ \\
\hline Men, $\mathrm{n}(\%)$ & $48(34.8)$ & $60(43.5)$ & 0.139 \\
Residence, urban, $\mathrm{n}(\%)$ & $125(90.6)$ & $128(92.8)$ & 0.513 \\
Mean age, years (SD) & $40.6(8.7)$ & $38.7(8.7)$ & 0.069 \\
Mean BMl, $\mathrm{kg} / \mathrm{m}^{2}$ (SD) & $24.6(4.7)$ & $23.0(3.6)$ & 0.001 \\
Median CD4 lymphocytes count, per mm ${ }^{3}$ & 333 & 274.5 & 0.016 \\
(IQR) & $(206-459.3)$ & $(159-408.3)$ & $\mathrm{NA}$ \\
Mean duration on ART, months (SD) & $30.2(13.1)$ & $\mathrm{NA}$ & $\mathrm{NA}$ \\
Active tuberculosis & 0 & $68(49.3)$ & $\mathrm{NA}$ \\
Past history of tuberculosis & $55(39.6)$ & 0 & \\
\hline
\end{tabular}

ART, antiretroviral therapy; BMI, body mass index; SD, standard deviation; NA, not applicable; IQR, interquartile range.

$34.8 \%$ vs. $43.5 \%, \mathrm{p}=0.139)$ and origin (\% urban: $90.6 \%$ vs. $92.8 \%, \mathrm{p}=0.51)$. ART participants were more likely to have high body mass index ( $\mathrm{p}=0.001)$ and high CD4 lymphocytes count $(\mathrm{p}=0.016)$.

\section{Lipid profile and first-line ART treatment}

Mean TC and mean LDL-c were higher in patients on ART than in ART-naïve patients (both $\mathrm{p}<0.02$ ). There was no significant difference between the two groups for HDL-c and triglycerides (Table 2). The prevalence of lipid profiles abnormalities is depicted in Table 3. The prevalence of $\mathrm{TC} \geq 200 \mathrm{mg} / \mathrm{dl}$ was $37.7 \%$ among ART group and $24.6 \%$ in the ART-naïve group ( $\mathrm{p}=0.013$ ). The equivalents for LDL-c $\geq 130 \mathrm{mg} / \mathrm{dl}$ were $46.4 \%$ and $21 \%, \mathrm{p}<0.001$; and those for TC/HDL-c ratio $\geq 5$ were $35.5 \%$ among patients on ART and $18.6 \%$ among ARTnaïve patients $(\mathrm{p}<0.001)$.

In multivariable analysis adjusted for age, sex, body mass index, CD4 count and co-infection with tuberculosis, being on ART was significantly and positively associated with raised total cholesterol, LDL-cholesterol and TC/HDL cholesterol. The adjusted odd ratios (95\% confidence interval, p-value) ART-treated vs. ART-naïve was 1.82 (1.061.12, $\mathrm{p}=0.02)$ for $\mathrm{TC} \geq 200 \mathrm{mg} / \mathrm{dl} ; 2.99$ (1.74-5.15), $\mathrm{p}<$ $0.0001)$ for LDL-cholesterol $\geq 130 \mathrm{mg} / \mathrm{dl}$ and 1.73 (1.04$2.89, \mathrm{p}=0.03$ ) for TC/HDL-cholesterol $\geq 5$ (Table 4).

Table 2 Value of different lipid parameters between firstline ART group and ART-naïve group in Yaounde, Cameroon

\begin{tabular}{llll}
\hline Lipid parameter & $\begin{array}{l}\text { First-line } \\
\text { ART treated } \\
\text { (n = 138) }\end{array}$ & $\begin{array}{l}\text { ART-naïve } \\
(\mathbf{n}=138)\end{array}$ & p \\
\hline Total cholesterol, mg/dl & $196(91)$ & $172(73)$ & 0.018 \\
HDL cholesterol, mg/dl & $49(26)$ & $49(25)$ & 0.944 \\
LDL cholesterol, mg/dl & $133(89)$ & $100(68)$ & 0.001 \\
Triglycerides, median, mg/dl (IQR) & $134(98-174)$ & $134(111-170)$ & 0.331 \\
TC/HDL-cholesterol ratio & $5.0(3.0)$ & $4.3(3.5)$ & 0.091 \\
\hline
\end{tabular}

Data are mean values ( \pm standard deviation) unless otherwise indicated. ART, antiretroviral therapy; $\mathrm{TC}$, total cholesterol; IQR, interquartile range.
Univariable and multivariable logistic regressions models were also used to investigate independent determinants of lipid derangements in the subgroup on ART alone. In both univariable and multivariable analyses, body mass index was the main determinant of raised LDL-c in ART-treated patients (Table 5).

\section{Lipid abnormalities and ART regimens}

Figures 1 and 2 show the prevalence of lipid abnormalities according to ART regimens. There was no significant difference in the prevalence of lipid abnormalities in patients on regimens that included $\mathrm{d} 4 \mathrm{~T}$ as compared with those on regimens that included AZT. The prevalence of lipid abnormalities induced by nevirapine and efavirenz was also similar in patients on ART.

\section{Discussion}

The aim of this study conducted in a resource-poor setting was to assess the prevalence of, and characterise lipid abnormalities associated with the use of first-line ART regimens that include nonnucleoside reverse transcriptase inhibitors (NNRTIs). We found that patients on first-line ART had high levels of total cholesterol, LDL-c and high TC/HDL-c ratio as compared with ART-naïve patients. Serum levels of HDL-c and triglycerides were similar between HIV-infected untreated patients and HIVinfected patients on ART. The described derangements

Table 3 Prevalence of abnormal lipid levels among firstline ART-treated patients and ART-naïve patients in Yaounde, Cameroon

\begin{tabular}{llll}
\hline Lipid parameter & $\begin{array}{l}\text { First-line } \\
\text { ART-treated } \\
\mathbf{n}=\mathbf{1 3 8}(\%)\end{array}$ & $\begin{array}{l}\text { ART-naïve } \\
\mathbf{n}=138(\%)\end{array}$ & $\mathbf{p}$ \\
\hline Total cholesterol $\geq 200 \mathrm{mg} / \mathrm{dl}$ & $52(37.7)$ & $33(24.6)$ & 0.013 \\
$\mathrm{HDL}$ cholesterol $<40 \mathrm{mg} / \mathrm{dl}$ & $55(39.9)$ & $51(37.0)$ & 0.620 \\
$\mathrm{LDL}$ cholesterol $\geq 130 \mathrm{mg} / \mathrm{dl}$ & $64(46.4)$ & $29(21.0)$ & $<0.001$ \\
Triglycerides $\geq 150 \mathrm{mg} / \mathrm{dl}$ & $60(43.5)$ & $53(38.4)$ & 0.392 \\
TC/HDL cholesterol ratio $\geq 5$ & $49(35.5)$ & $19(13.8)$ & $<0.001$ \\
\hline
\end{tabular}

$\mathrm{ART}$, antiretroviral therapy; $\mathrm{TC}$, total cholesterol. 
Table 4 HIV treatment and other determinants of abnormal lipid profile in HIV-infected individuals in Yaounde, Cameroon

\begin{tabular}{|c|c|c|c|}
\hline Outcome variables & Explanatory variables & $\begin{array}{l}\text { Adjusted OR } \\
(95 \% \mathrm{Cl})\end{array}$ & $\mathbf{P}$ \\
\hline \multirow[t]{6}{*}{$\mathrm{TC} \geq 200(\mathrm{mg} / \mathrm{dl})$} & Antiretroviral therapy & $1.82(1.06-3.12)$ & 0.02 \\
\hline & Sex (Women vs. Men) & $0.83(0.48-1.43)$ & 0.49 \\
\hline & Age $>40$ years & $1.27(0.74-2.17)$ & 0.39 \\
\hline & $\mathrm{BMI}>25 \mathrm{~kg} / \mathrm{m}^{2}$ & $1.05(0.59-1.86)$ & 0.87 \\
\hline & Active tuberculosis & $0.49(0.28-0.86)$ & 0.01 \\
\hline & CD4 count $\leq 200 / \mathrm{mm}^{3}$ & $2.56(0.34-20.00)$ & 0.36 \\
\hline \multirow[t]{6}{*}{ LDL-c $\geq 130(\mathrm{md} / \mathrm{dl})$} & Antiretroviral therapy & $2.99(1.74-5.15)$ & $<0.0001$ \\
\hline & Sex (Women vs. Men) & $1.06(0.61-1.82)$ & 0.84 \\
\hline & Age $>40$ years & $1.13(0.66-1.94)$ & 0.65 \\
\hline & $\mathrm{BMI}>25 \mathrm{~kg} / \mathrm{m}^{2}$ & $1.87(1.07-3.27)$ & 0.02 \\
\hline & Active tuberculosis & $0.54(0.31-0.95)$ & 0.03 \\
\hline & CD4 count $\leq 200 / \mathrm{mm}^{3}$ & $1.92(0.24-15.74)$ & 0.54 \\
\hline \multirow[t]{6}{*}{$\mathrm{TC} / \mathrm{HDL}-\mathrm{C}$ ratio $\geq 5$} & Antiretroviral therapy & $1.73(1.04-2.89)$ & 0.03 \\
\hline & Sex (Women vs. Men) & $1.88(1.11-3.20)$ & 0.02 \\
\hline & Age $>40$ years & $1.49(0.89-2.50)$ & 0.20 \\
\hline & $\mathrm{BMI}>25 \mathrm{~kg} / \mathrm{m}^{2}$ & $0.68(0.40-1.17)$ & 0.16 \\
\hline & Active tuberculosis & $1.12(0.67-1.89)$ & 0.68 \\
\hline & CD4 count $\leq 200 / \mathrm{mm}^{3}$ & $1.78(0.22-14.43)$ & 0.59 \\
\hline
\end{tabular}

BMI, body mass index; OR, odds ratio; Cl, confidence interval; LDL-c, LDL cholesterol;

TC, total cholesterol; HDL-c, HDL cholesterol.

Table 5 Determinants of abnormal lipid profile in 138 first-line ART treated individuals in Yaounde, Cameroon

\begin{tabular}{|c|c|c|c|c|c|}
\hline Outcome variables & Explanatory variables & $\begin{array}{l}\text { OR } \\
(95 \% \mathrm{Cl})\end{array}$ & $p^{a}$ & $\begin{array}{l}\text { Ajusted OR } \\
(95 \% \mathrm{Cl})\end{array}$ & $p^{b}$ \\
\hline \multirow[t]{7}{*}{$\mathrm{TC} \geq 200(\mathrm{mg} / \mathrm{dl})$} & Sex (Women vs. Men) & $0.99(0.48-2.04)$ & 0.99 & $0.96(0.45-2.03)$ & 0.93 \\
\hline & Age $>40$ years & $1.38(0.69-2.76)$ & 0.36 & $1.41(0.69-2.91)$ & 0.35 \\
\hline & $\mathrm{BMI}>25 \mathrm{~kg} / \mathrm{m}^{2}$ & $1.22(0.59-2.52)$ & 0.59 & $1.06(0.49-2.29)$ & 0.88 \\
\hline & Treatment duration $>2$ years & $2.07(1.03-4.17)$ & 0.04 & $2.08(1.01-4.27)$ & 0.05 \\
\hline & $\mathrm{d} 4 \mathrm{~T}$ vs. AZT regimen & $0.75(0.36-1.56)$ & 0.44 & $0.78(0.32-1.81)$ & 0.55 \\
\hline & NVP vs. EFV regimen & $0.79(0.26-2.41)$ & 0.67 & $0.79(0.21-2.99)$ & 0.73 \\
\hline & Past history of tuberculosis & $0.80(0.39-1.62)$ & 0.54 & $0.85(0.41-1.80)$ & 0.68 \\
\hline \multirow[t]{7}{*}{$\mathrm{LDL}-\mathrm{c} \geq 130(\mathrm{md} / \mathrm{dl})$} & Sex (Women vs. Men) & $0.70(0.33-1,51)$ & 0.32 & $0.67(0.32-1.40)$ & 0.29 \\
\hline & Age $>40$ years & $0.74(0.36-1.54)$ & 0.38 & $0.57(0.28-1.18)$ & 0.23 \\
\hline & $\mathrm{BMI}>25 \mathrm{~kg} / \mathrm{m}^{2}$ & $2.23(1.04-4.80)$ & 0.02 & $2.65(1.24-5.68)$ & 0.01 \\
\hline & Treatment duration $>2$ years & $0.93(0.45-1.93)$ & 0.83 & $0.87(0.42-1.80)$ & 0.71 \\
\hline & $\mathrm{d} 4 \mathrm{~T}$ vs. $\mathrm{AZT}$ regimen & $1.73(0.79-3.78)$ & 0.13 & $1.71(0.72-4.06)$ & 0.22 \\
\hline & NVP vs. EFV regimen & $1.18(0.34-4.01)$ & 0.77 & $0.99(0.26-3.72)$ & 0.98 \\
\hline & Past history of tuberculosis & $1.54(0.73-3.25)$ & 0.22 & $1.72(0.89-3.62)$ & 0.15 \\
\hline \multirow[t]{7}{*}{$\mathrm{TC} / \mathrm{HDL}-\mathrm{C}$ ratio $\geq 5$} & Sex (Women vs. Men) & $1.79(0.79-4.14)$ & 0.13 & $1.61(0.73-3.54)$ & 0.23 \\
\hline & Age $>40$ years & $0.67(0.31-1.43)$ & 0.26 & $0.72(0.34-1.50)$ & 0.38 \\
\hline & $\mathrm{BMI}>25 \mathrm{~kg} / \mathrm{m}^{2}$ & $0.99(0.45-2.16)$ & 0.97 & $0.88(0.41-1.89)$ & 0.74 \\
\hline & Treatment duration $>2$ years & $1.93(0.60-2.97)$ & 0.08 & $1.90(0.89-4.06)$ & 0.1 \\
\hline & $\mathrm{d} 4 \mathrm{~T}$ vs. AZT regimen & $1.33(0.60-2.97)$ & 0.44 & $1.56(0.66-3.73)$ & 0.31 \\
\hline & NVP vs. EFV regimen & $1.01(0.27-3.58)$ & 1 & $0.68(0.17-2.65)$ & 0.58 \\
\hline & Past history of tuberculosis & $0.72(0.34-1.56)$ & 0.37 & $0.77(0.37-1.63)$ & 0.5 \\
\hline
\end{tabular}

BMI, body mass index; OR, odds ratio; $\mathrm{Cl}$, confidence interval; LDL-c, LDL cholesterol; TC, total cholesterol; HDL-c, HDL cholesterol; $\mathrm{p}^{\mathrm{a}}$, $\mathrm{p}$ value for unadjusted odds ratio; $\mathrm{p}^{\mathrm{b}}, \mathrm{p}$ value for adjusted odds ratio 


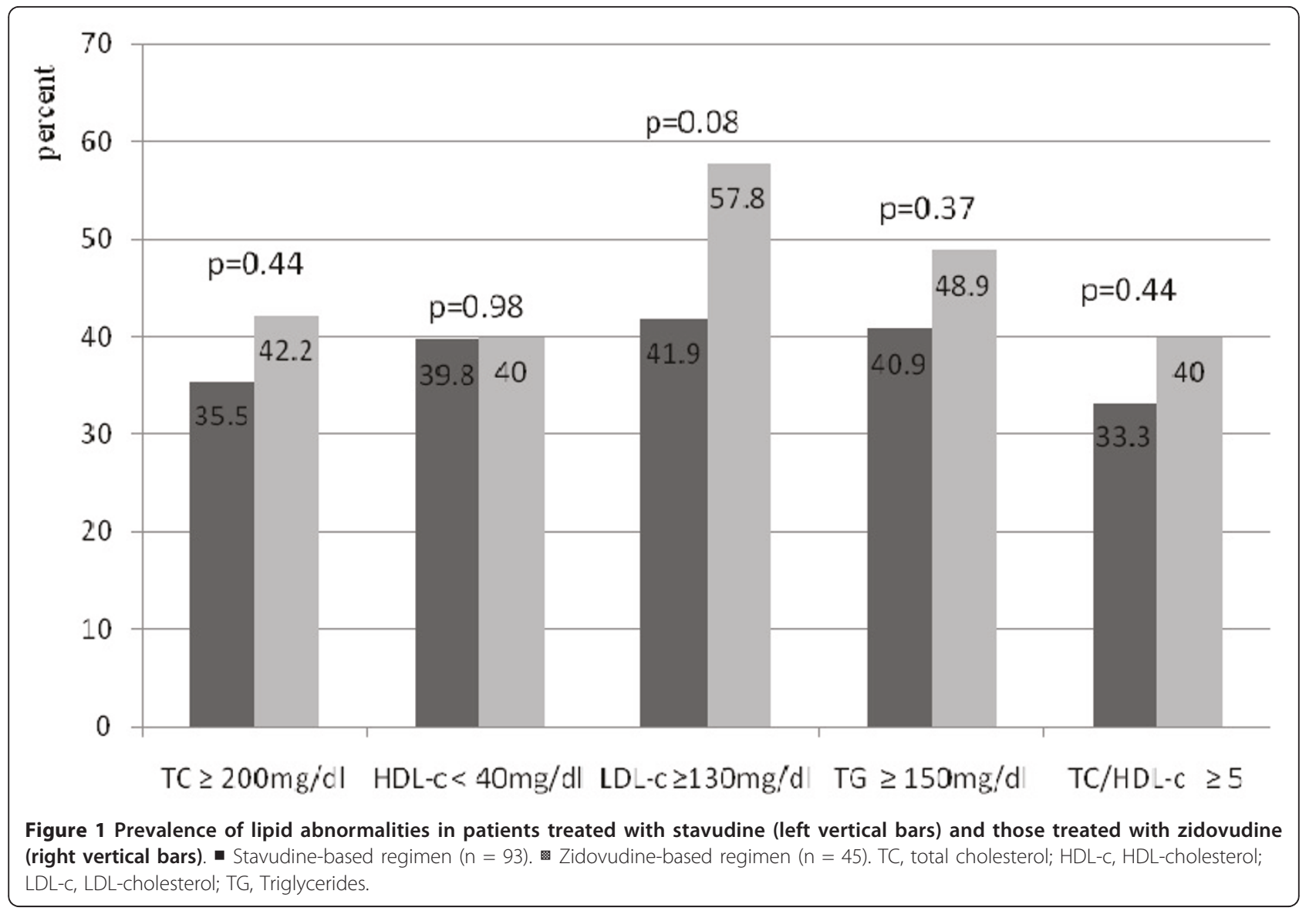

that are potentially atherogenic [14], were still present after adjustment for potential confounders.

The association between HAART and adverse lipid profile has been largely described for regimens that include protease inhibitors (PIs) [4,16-19]. It is well known that PIs and NNRTIs induce derangements of lipid profile during ART [3-5,17,20]. However, evidence in support of the adverse effects of NNRTIs on lipid profile of HIV treated patients in sub-Saharan Africa are very limited [11,12]. The proportion of patients with high total cholesterol among our ART treated participant was similar to that reported by Zannou et al in the cohort in Benin [12], but higher than the rate found in rural Ugandans [11]. These two studies were cohort studies wherein participants were followed for a 24 months period for the onset of lipid derangements. However, there are suggestions that the magnitude of first-line ART induced lipid derangements could vary across populations and settings. Cross-sectional studies from other resources-constrained settings have reported prevalence of high level of total cholesterol ranging from 23 to $41 \%$ in patients treated with NNRTIbased regimens $[15,21]$. Based on LDL-c cut-points, we found a prevalence of dyslipidemia that was higher than that reported in Uganda [11] and in India [15]. Prevalence rates in these two studies were respectively $6 \%$ and $30 \%$. Similarly, in these two studies the prevalence of high LDLc prior to ART was also lower than that found in our study ( $\leq 4 \%$ vs. $21 \%$ ). The HDL-c and triglycerides levels were unaffected by first-line HAART in our study is not in accordance with the findings of Pujari and his colleagues in India [15]. In this study, an 18-month treatment with first-line ART regimens was associated with significant increase in HDL-c and triglycerides.

Several studies have found that stavudine was more involved in the occurrence of lipid derangements as compared with other NRTIs [22,23]. We found no difference in lipid profiles when participants on stavudine were compared to those on zidovudine. This is in line with the findings of Buchacz et al in Uganda [11], and those of Pujari et al in India [15]. The two NNRTIs included in the WHO first-line regimens are nevirapine and efavirenz. Two studies have found that patients treated with nevirapine had a better lipid profile than those treated with efavirenz $[24,25]$. In accordance with Buchacz et al [11], we found no difference in the lipid profile of patients on nevirapine compared with those on efavirenz. In our study, high LDL-c was associated with ART use, but also with body mass index, including in the subgroup only on ART. The 


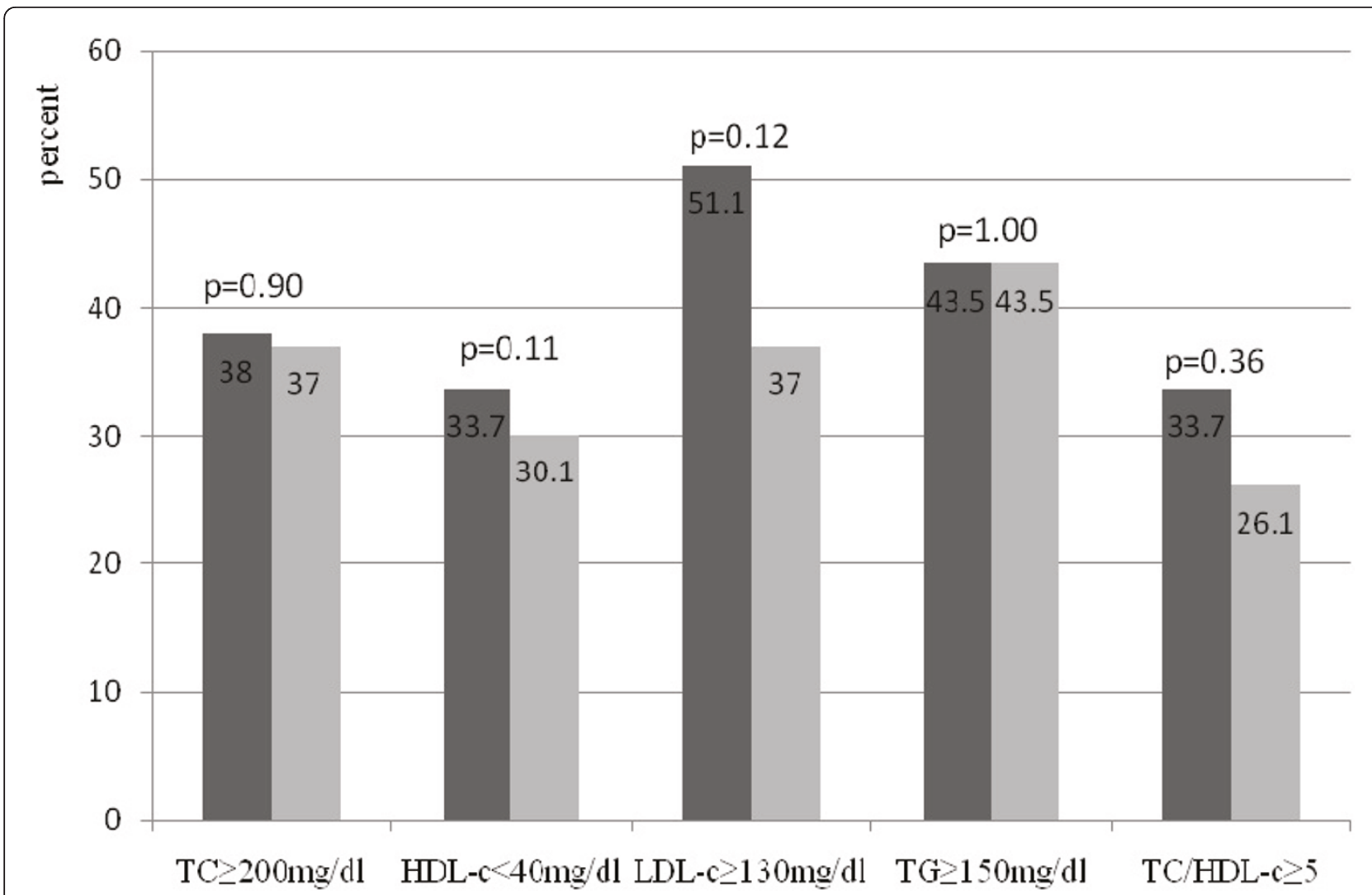

Figure 2 Prevalence of lipid abnormalities in patients treated with nevirapine (left vertical bars) vs. those treated with efavirenz (right vertical bars). - Nevirapine-based regimen $(n=92)$. . Efavirenz-based regimen $(n=46)$. TC, total cholesterol; HDL-c, HDL-cholesterol; LDL-c, LDL-cholesterol; TG, Triglycerides.

association of high LDL-c with obesity is well known [26]. It is therefore possible that our findings reflect more these well known lipid derangements associated with obesity than sides effects of ART.

Our study did not assess the global cardiovascular risk of participants. However, the increased risk of atherothombotic cardiovascular disease associated with the described lipid derangement is well know $[4,5,7,8,27]$ and would therefore suggest that treatment with first-line ART may actually have harmful effects on the cardiovascular health of our population. Our study, by nature is cross-sectional and inference about causal relationship is not possible. Cohorts' studies would be indicated to monitor lipid profile alterations during first-line ART, and their potential impact on cardiovascular health of people living with HIV in our settings. The other limitation of our study is the lack of HIV-negative controls. In fact untreated HIV infection is associated with low LDL-c and low HDL-c [28], particularly in those patients with severe immune-depression [29]. It is therefore possible that high levels of LDL-c found in our study actually just reflect a "catch-up phenomenon". However, the higher median CD4 count in our HIV-naive subgroup would tend to suggest that they were less likely to have severe immune-depression type lipid profile [29]. In this context, their lipid profile is likely closer to that in the general population without HIV infection. This would also minimise limitations relating to the lack of a non HIV infected control subgroup.

\section{Conclusion}

In conclusion, WHO first-line HAART with regimens that include NNRTIs are associated with potentially atherogenic adverse lipid profile in patients with HIV-1 infection compared to untreated HIV-infected patients in our setting. This may indicate the need to update the current recommendations of WHO pertaining to biological monitoring of patients on first-line antiretroviral therapy to include lipid panel. Lipid profile and other cardiovascular risk factors should be monitored in patients on such therapy so that any untoward effects of ART can be optimally managed.

\section{List of abbreviations}

3TC: lamivudine; ART: antiretroviral therapy; AZT: zidovudine; d4T: stavudine; EFV: efavirenz; HAART: highly active antiretroviral therapy; HDL-c: HDLcholesterol; HIV: human immunodeficiency virus; LDL-c: LDL-cholesterol; 
NNRTIs: nonnucleoside reverse transcriptase inhibitors; NVP: névirapine; Pls: protease inhibitors; TC: total cholesterol; TG: triglycerides Statical package for social sciences (SPSS); WHO: World Health Organisation.

\section{Acknowledgements}

We want to acknowledge the laboratory technicians of the biochemistry laboratory of Yaounde University Center. Our gratitude is also extended to the HIV/AIDS patients for their collaboration during this study.

\section{Author details}

${ }^{1}$ Chest Unit of Yaounde Jamot Hospital, Cameroon. ${ }^{2}$ Faculty of Medicine and Biomedical Sciences, University of Yaounde I, Cameroon. ${ }^{3}$ Biochemistry laboratory of Yaounde University Center, Cameroon. ${ }^{4}$ South African Medical Research Council \& department of Medicine, University of Cape Town, Francie van Zijl Drive, Parow Valley, 7505 Cape Town, South Africa. ${ }^{5}$ Medicine Unit of Yaounde General Hospital, Cameroon.

\section{Authors' contributions}

EWPY conceived and designed the study, performed analysis and interpretation of data and drafted the manuscript, AFB and APK assisted with the design, interpretation of data and the critical review of the manuscript. JFKF and JN performed critical review of the manuscript All authors approved and read the final manuscript.

\section{Competing interests}

The authors declare that they have no competing interests.

Received: 5 June 2011 Accepted: 26 September 2011

Published: 26 September 2011

\section{References}

1. Palella FJ Jr, Delaney KM, Moorman AC, Loveless MO, Fuhrer J, Satten GA, Aschman DJ, Holmberg SD: Declining morbidity and mortality among patients with advanced human immunodeficiency virus infection. HIV Outpatient Study Investigators. N Engl J Med 1998, 338:853-60.

2. Kumar A, Kilaru KR, Forde S, Roach TC: Changing HIV infection-related mortality rate and causes of death among persons with HIV infection before and after the introduction of highly active antiretroviral therapy: analysis of all HIV-related deaths in Barbados, 1997-2005. J Int Assoc Physicians AIDS Care(Chic) 2006, 5:109-14.

3. Heath KV, Chan KJ, Singer J, O'Shaughnessy MV, Montaner JS, Hogg RS: Incidence of morphological and lipid abnormalities: gender and treatment differentials after initiation of first antiretroviral therapy. Int $J$ Epidemiol 2002, 31:1016-20.

4. Grunfeld C: Dyslipidemia and its Treatment in HIV Infection. Top HIV Med 2010, 18:112-8.

5. Domingos H, Cunha RV, Paniago AM, Martins DM, Elkhoury EB, Souza AS: Metabolic effects associated to the highly active antiretroviral therapy (HAART) in AIDS patients. Braz J Infect Dis 2009, 13:130-6.

6. Padmapriyadarsini $C$, Ramesh Kumar $S$, Terrin N, Narendran G, Menon PA, Ramachandran G, Subramanyan S, Venkatesan P, Wanke C, Swaminathan S: Dyslipidemia among HIV-infected Patients with tuberculosis taking once-daily nonnucleoside reverse-transcriptase inhibitor-based antiretroviral therapy in India. Clin Infect Dis 2011, 52:540-6.

7. Currier JS, Lundgren JD, Carr A, Klein D, Sabin CA, Sax PE, Schouten JT, Smieja M, Working Group 2: Epidemiological evidence for cardiovascular disease in HIV-infected patients and relationship to highly active antiretroviral therapy. Circulation 2008, 118:e29-35.

8. Bozkurt B: Cardiovascular toxicity with highly active antiretroviral therapy: review of clinical studies. Cardiovasc Toxicol 2004, 4:243-60.

9. World Health Organization: Antiretroviral therapy for HIV infection in adults and adolescents in resource-limited settings: towards universal access. 2006 revision.[http://www.who.int/hiv/pub/arv/adult/fr/index.html], Accessed on 10 October 2010.

10. Organisation Mondiale de la Santé: Recommandations rapides: Traitement antirétroviral de l'infection à VIH chez l'adulte et l'adolescent.[http:// www.who.int/hiv/pub/arv/rapid_advice_art_fr.pdf], Accessed on 12 December 2011.

11. Buchacz K, Weidle PJ, Moore D, Were W, Mermin J, Downing R, Kigozi A, Borkowf CB, Ndazima V, Brooks JT: Changes in lipid profile over 24 months among adults on first-line highly active antiretroviral therapy in the home-based AIDS care program in rural Uganda. J Acquir Immune Defic Syndr 2008, 47:304-11.

12. Zannou DM, Denoeud L, Lacombe K, Amoussou-Guenou D, Bashi J, Akakpo J, Gougounon A, Akondé A, Adé G, Houngbé F, Girard PM: Incidence of lipodystrophy and metabolic disorders in patients starting non-nucleoside reverse transcriptase inhibitors in Benin. Antivir Ther 2009, 14:371-80.

13. Chesney MA, Ickovics JR, Chambers DB, Gifford AL, Neidig J, Zwickl B, Wu AW: Self-reported adherence to antiretroviral medications among participants in HIV clinical trials: the AACTG adherence instruments. Patient Care Committee \& Adherence Working Group of the Outcomes Committee of the Adult AIDS Clinical Trials Group (AACTG). AIDS Care 2000, 12:255-66.

14. Expert Panel on Detection and Treatment of High Blood Cholesterol in Adults: Executive Summary of The Third Report of The National Cholesterol Education Program (NCEP) Expert Panel on Detection, Evaluation, And Treatment of High Blood Cholesterol In Adults (Adult Treatment Panel III). JAMA 2001, 285:2486-97.

15. Pujari SN, Dravid A, Naik E, Bhagat S, Tash K, Nadler JP, Sinnott JT: Lipodystrophy and dyslipidemia among patients taking first-line, World Health Organization-recommended highly active antiretroviral therapy regimens in Western India. J Acquir Immune Defic Syndr 2005, 39:199-202.

16. Calza L, Manfredi R, Chiodo F: Dyslipidaemia associated with antiretroviral therapy in HIV-infected patients. Antimicrob Chemother 2004, 53:10-4.

17. Domingos H, Cunha RV, Paniago AM, Martins DM, Elkhoury EB, Souza AS: Metabolic effects associated to the highly active antiretroviral therapy (HAART) in AIDS patients. Braz J Infect Dis 2009, 13:130-6.

18. Jones R, Sawleshwarkar S, Michailidis C, Jackson A, Mandalia S, Stebbing J, Bower M, Nelson M, Gazzard BG, Moyle GJ: Impact of antiretroviral choice on hypercholesterolaemia events: the role of the nucleoside reverse transcriptase inhibitor backbone. HIV Med 2005, 6:396-402.

19. Fontas $E$, van Leth F, Sabin CA, Friis-Møller N, Rickenbach M, d'Arminio Monforte A, Kirk O, Dupon M, Morfeldt L, Mateu S, Petoumenos K, ElSadr W, de Wit S, Lundgren JD, Pradier C, Reiss P, D:A:D Study Group: Lipid profiles in HIV-infected patients receiving combination antiretroviral therapy: are different antiretroviral drugs associated with different lipid profiles? J Infect Dis 2004, 189:1056-74.

20. Young J, Weber R, Rickenbach M, Furrer H, Bernasconi E, Hirschel B, Tarr PE, Vernazza P, Battegay M, Bucher HC: Lipid profiles for antiretroviral-naïve patients starting PI- and NNRTI-based therapy in the Swiss HIV cohort study. Antivir Ther 2005, 10:585-91.

21. Almeida SE, Borges M, Fiegenbaum M, Nunes CC, Rossetti ML: Metabolic changes associated with antiretroviral therapy in HIV-positive patients. Rev Saude Publica 2009, 43:283-90.

22. Galli M, Ridolfo AL, Adorni F, Gervasoni C, Ravasio L, Corsico L, Gianelli E, Piazza M, Vaccarezza M, d'Arminio Monforte A, Moroni M: Body habitus changes and metabolic alterations in protease inhibitor-naive HIV-1infected patients treated with two nucleoside reverse transcriptase inhibitors. J Acquir Immune Defic Syndr 2002, 29:21-31.

23. Gallant JE, Staszewski S, Pozniak AL, DeJesus E, Suleiman JM, Miller MD, Coakley DF, Lu B, Toole JJ, Cheng AK, 903 Study Group: Efficacy and safety of tenofovir DF vs stavudine in combination therapy in antiretroviralnaive patients: a 3-year randomized trial. JAMA 2004, 292:191-201.

24. van der Valk M, Kastelein JJ, Murphy RL, van Leth F, Katlama C, Horban A, Glesby M, Behrens G, Clotet B, Stellato RK, Molhuizen HO, Reiss P, Atlantic Study Team: Nevirapine-containing antiretroviral therapy in HIV-1 infected patients results in an antiatherogenic lipid profile. AIDS 2001, 15:2407-14.

25. van Leth F, Phanuphak P, Stroes E, Gazzard B, Cahn P, Raffi F, Wood R, Bloch M, Katlama C, Kastelein JJ, Schechter M, Murphy RL, Horban A, Hall DB, Lange JM, Reiss P: Nevirapine and efavirenz elicit different changes in lipid profiles in antiretroviral therapy-naïve patients infected with HIV. -1. PLos Med 2004, 1:e19.

26. Rader DJ, Hobbs HH: Disorders of lipoprotein metabolism. In Harrison's principles of Internal Medicine.. 16 edition. Edited by: Kasper DL, Braunwald $\mathrm{E}$, Fauci AS, Hauser SL, Longo DL, Larry Jamerson J. New York: Mc Graw-Hill Companies; 2005:2294-2295.

27. Cahn P, Leite O, Rosales A, Cabello R, Alvarez CA, Seas C, Carcamo C, CureBolt N, L'Italien GP, Mantilla P, Deibis L, Zala C, Suffert T: Metabolic profile and cardiovascular risk factors among Latin American HIV-infected patients receiving HAART. Braz J Infect Dis 2010, 14:158-66. 
28. Nguemaïm NF, Mbuagbaw J, Nkoa T, Alemnji G, Této G, Fanhi TC, Asonganyi T, Samé-Ekobo A: Serum lipid profile in highly active antiretroviral therapy-naïve HIV-infected patients in Cameroon: a casecontrol study. HIV Med 2010, 11:353-9.

29. Riddler SA, Smit E, Cole SR, Li R, Chmiel JS, Dobs A, Palella F, Visscher B, Evans R, Kingsley LA: Impact of HIV infection and HAART on serum lipids in men. JAMA 2003, 289:2978-82.

doi:10.1186/1742-6405-8-33

Cite this article as: Pefura Yone et al:: First-line antiretroviral therapy and dyslipidemia in people living with HIV-1 in Cameroon: a cross-sectional study. AIDS Research and Therapy 2011 8:33.

Submit your next manuscript to BioMed Central and take full advantage of:

- Convenient online submission

- Thorough peer review

- No space constraints or color figure charges

- Immediate publication on acceptance

- Inclusion in PubMed, CAS, Scopus and Google Scholar

- Research which is freely available for redistribution

Submit your manuscript at www.biomedcentral.com/submit 